\title{
PIJAT TUNA EFEKTIF DALAM MENGATASI KESULITAN MAKAN PADA ANAK BALITA
}

\author{
Yusari Asih*, Mugiati* \\ *Jurusan Kebidanan Poltekkes Tanjungkarang \\ E-mail: yusariasih@gmail.com
}

\begin{abstract}
Masalah yang sering terjadi dalam pemenuhan nutrisi yakni kesulitan makan pada balita yang dapat menyebabkan terjadinya gangguan tumbuh kembang atau stunting. Upaya untuk mengatasi kesulitan makan dapat dilakukan dengan cara farmakologi maupun non farmakologi. Upaya dengan farmakologi antara lain dengan pemberian miltivitamin, sedangkan non farmakologi antara lain melalui minuman herbal/jamu, pijat, akupresur, dan akupunktur. Masalah dalam penelitian ini adalah tingginya angka BGM dan kejadian keluhan sulit makan pada anak balita yang berkunjung ke BPM. Desain penelitian ini adalah quasi eksperimen yang melibatkan kelompok eksperimen dan kelompok kontrol. Populasi yang digunakan adalah semua anak balita yang ada di wilayah Kecamatan Pagelaran berjumlah 2920 balita, dengan jumlah sampel sebanyak 100 responden. Data penelitian dikumpulkan dengan menggunakan kuesioner dan perlakuan langsung menggunakan job sheet. Analisis data melalui Uji T dengan nilai kemaknaan alpha 0,05. Hasil penelitian menunjukkan rata-rata kesulitan makan pada anak yang dilakukan pijat tuina adalah 3.360 dengan standar deviasi 0,921 , sedangkan untuk anak balita yang diberi multivitamin rata-rata kesulitan makannya adalah 2.260 dengan standar deviasi 1.337. Hasil uji statistik didapatkan nilai $\mathrm{p}=0,000$, berarti dengan alpha $5 \%$ terlihat ada perbedaan yang signifikan rata-rata kesulitan makan pada anak balita antara anak balita yang dilakukan pijat tuina dengan anak balita yang diberikan multivitamin. Simpulan dari penelitian ini pijat Tui Na yang dilakukan sesuai prosedur, dengan 8 rangkaian pijat dapat mengatasi kesulitan makan pada balita. Diharapkan agar ibu balita mampu dan rutin menerapkan pijat ini dalam mengatasi kesulitan makan pada anaknya, bidan dapat memberikan edukasi dan pelatihan pada ibu balita sehingga setiap ibu mampu melaksanakan pijat tui na ini.
\end{abstract}

Kata Kunci: Kesulitan Makan, Pijat Tuina

\section{LATAR BELAKANG}

Kesulitan makan merupakan
masalah dalam pemberian makanan
maupun pemenuhan kebutuhan gizi yang
pada umumnya dijumpai pada anak dan
menjadi masalah kesehatan di seluruh
dunia (Chung, 2006). Sebagian besar kesulitan makan pada bayi berkaitan dengan gangguan pertumbuhan, sedangkan kesulitan makan pada anak disertai dengan gangguan perkembangan. Kesulitan makan pada anak yang tidak segera ditangani dapat menyebabkan malnutrisi, dehidrasi, berat badan kurang, ketidakseimbangan elektrolit, gangguan perkembangan kognitif, gangguan kecemasan, dan pada keadaan yang lebih parah dapat menjadi kondisi yang mengancam hidup (Antolis, 2012).

Berdasarkan penelitian-penelitian yang dilakukan dalam beberapa tahun dibanyak negara, dapat diketahui prevalensi kesulitan makan pada anak termasuk tinggi. Penelitian pada tahun 2004 menunjukkan bahwa 50\% dari 3.022 balita di Amerika mengalami kesulitan makan.Penelitian lain di Amerika Serikat menunjukkan prevalensi kesulitan makan pada anak-anak yang normal secara fisik berdasarkan laporan dari orang tua yang mengalami kesulitan dalam pemberian makan adalah 50-60\%. Sekitar $25 \%$ anak normal dan $80 \%$ anak yang memiliki gangguan perkembangan, mengalami kesulitan makan. Disamping itu, didapatkan 1-2 \% bayi dengan kesulitan makan serius berkaitan dengan gangguan pertumbuhan (Antolis, 2012).

Penelitian di Finlandia pada tahun 2004, menunjukkan 30\% dari 494 anak yang diteliti terdiagnosis mengalami masalah makan. Pada penelitian terhadap anak prasekolah usia 4-6 tahun di Jakarta, didapatkan prevalensi kesulitan makan sebesar $33,6 \%$ dan $44,5 \%$ di antaranya 
menderita malnutrisi ringan sampai sedang, 79,2\% dari subjek penelitian telah menderita kesulitan makan lebih dari 3 bulan (Lubis, 2005).

Proses belajar makan anak dipengaruhi oleh berbagai macam faktor. Jika terdapat gangguan atau hambatan pada faktor-faktor tersebut, dapat berdampak pula pada ketrampilan makan anak yang kemudian dapat berkembang menjadi kesulitan makan pada anak. Beberapa penelitian menunjukkan adanya riwayat bayi berat lahir rendah pada anak yang mengalami kesulitan makan.Ketidaktahuan ibu dalam memberi ASI, MP-ASI, dan susu formula dapat menyebabkan kesulitan makan pada anak. Pemberian ASI yang terlalu lama (prolonged breastfeeding) dapat menyebabkan anak terlambat melatih gerakan-gerakan dasar serta refleks untuk makan sehingga perkembangan ketrampilan makan pada anak menjadi terhambat yang dapat berlanjut menjadi kesulitan makan. Suatu penelitian menyatakan adanya penurunan selera makan pada anak yang terlalu lama diberikan ASI melebihi standar dari WHO, yakni lebih dari 6 bulan (WHO, 2013).

Kesulitan makan sering dialami oleh anak terutama rentang usia 1-3 tahun yang disebut juga usia food jag, yaitu anak hanya makan pada makanan yang disukai atau bahkan sulit makan, seringkali hal ini dianggap wajar namun keadaan sulit makan yang berkepanjangan akan menimbulkan masalah pada pertumbuhan dan perkembangan anak. Gangguan fungsi limpa dan pencernaan menjadi penyebab paling dominan pada anak dengan kesulitan makan. Gangguan fungsi saluran cerna kronis seperti alergi makanan, intoleransi makanan, penyakit coeliac. Reaksi simpang makanan tersebut tampaknya sebagai penyebab utama gangguan-gangguan tersebut. Hal ini bisa dilihat dengan timbulnya permasalahan kesulitan makan.

Berbagai macam faktor yang menjadi penyebab kesulitan makan dapat diklasifikasikan menjadi 3 faktor utama yang pada umumnya berkaitan dengan gagal tumbuh, yaitu faktor organik, faktor non organik, dan gabungan antara faktor organik dan non organik.Dimana faktor organik meliputi ketidakmampuan untuk menerima nutrisi secara adekuat, ketidakmampuan menggunakan kalori secara adekuat, adanya peningkatan kebutuhan kalori, serta perubahan/gangguan potensi pertumbuhan. Sedangkan faktor non organik mencakup ketidakmampuan orang tua untuk menyediakan asupan nutrisi secara adekuat, faktor psikososial, serta ketidaktahuan/ informasi yang salah mengenai cara pemberian makan (Antolis, 2012).

Kesulitan makan pada anak berisiko tinggi menjadi malnutrisi seiring dengan bertambahnya usia. Hal ini dapat diidentifikasi dan ditindaklanjuti secara dini melalui pengukuran status gizi pada anak dengan kesulitan makan agar terhindar dari salah satu komplikasinya yaitu malnutrisi.

Upaya untuk mengatasi kesulitan makan dapat dilakukan dengan cara farmakologi maupun non farmakologi. Upaya dengan farmakologi antara lain dengan pemberian miltivitamin, dan micronutrien lainnya. Sedangkan non farmakologi antara lain melalui minuman herbal/jamu, pijat, akupresur, dan akupunktur.

Saat ini kebanyakan orang tua mengatasi kesulitan makan anak sebatas pemberian multivitamin tanpa memperhatikan penyebab. Hal tersebut akan berdampak negatif jika diberikan dalam jangka waktu yang lama. Dewasa ini telah dikembangkan dari tehnik pijat bayi, yakni pijat Tui Na. Pijat ini dilakukan dengan tehnik pemijatan meluncur untuk mengatasi kesulitan makan pada balita dengan cara memperlancar peredaran darah pada limpa dan pencernaan, melalui modifikasi dari akupunktur tanpa jarum, teknik ini menggunakan penekanan pada titik meridian tubuh atau garis aliran energi sehingga relatif lebih mudah dilakukan dibandingkan akupuntur 
Akupresur memiliki sistem dan titik terapi yang cukup banyak, sehingga jika akupresur harus dilakukan di keseluruhan titik maka metode ini akan cukup sulit dilaksanakan oleh bidan ataupun keluarga pasien sebagai asuhan rutin pada anak balita, padahal pada dasarnya setiap titik pada metode akupresur memiliki fungsi tertentu sesuai kebutuhan fisik klien, sehingga akupresur dapat menjadi sangat mudah untuk dilakukan jika terpusat pada titik terkait yang sesuai dengan kebutuhan saja, misalnya pada Pijat Tui $\mathrm{Na}$ ini yang terbatas pada titik meridian tangan, kaki, perut dan pungung. Ketentuan pijat ini yakni 1 set terapi sama dengan $1 \mathrm{x}$ protokol terapi per hari, selama 6 hari berturut-turut, bila perlu mengulang terapi beri jeda 1-2 hari dan pijat salah satu sisi tangan saja, tidak perlu kedua sisi, jangan paksa anak makan karena akan menimbulkan trauma psikologis. Berikan asupan makanan yang sehat, bergizi dan bervariasi

Hasil penelitian Zhen Huan Liu dan Li ting Cen di Guangzhou tahun 2009 menyebutkan bahwa pijat Tui na berpengaruh positif terhadap perkembangan syaraf dan peredaran darah pada bayi. Penelitian serupa juga dilakukan oleh Mehta Berdasarkan hal tersebut peneliti perlu mengkaji lebih lanjut efektifitas pijat $T u i \quad N a$ dalam mengatasi kesulitan makan pada balita, dengan tetap mengedepankan keamanan dan asuhan sayang anak.

Berdasarkan Data berdasarkan Profil Dinkes Pringsewu, tahun 2015, dari 11 Puskesmas yang ada di kabupaten Pringsewu, terdapat 41.518 balita, 73,1\% diantaranya datang dan ditimbang dan $22 \%$ termasuk kategori Bawah Garis Merah (BGM). Jumlah BGM tertinggi berada di Wilayah Puskesmas Pagelaran, yaitu 37 balita $(1.8 \%)$ dari 2.052 balita. Sementara, di Wilayah terdekat yaitu Puskesmas Pringsewu, kejadian BGM sebesar 0,4\% (24) dari 6.283 balita.

Berdasarkan pre survey di 4 BPM Wilayah Kerja Puskesmas Pagelaran, di dapat data dari 40 balita yang berkunjung, $25(62,5 \%)$ balita orangtuanya mengeluh anaknya tidak mau makan, dan meminta multivitamin untuk mengatasi masalah tersebut. Dari 40 orang tua yang berkunjung tidak ada yang mengetahui alternatif lain untuk mengatasi masalah tersebut selain dengan memberikan multivitamin.

\section{METODE}

Penelitian ini dilakukan bertujuan untuk mengetahui pengaruh Pijat Tui $\mathrm{Na}$ dalam mengatasi kesulitan makan pada anak balita. Penelitian ini menggunakan desain quasi experiment dengan rancangan pretest dan post test design untuk membandingkan objek penelitian dan mengukur tingkat kesulitan makan pada kelompok intervensi (diberikan perlakuan pijat Tuina) dan kelompok kedua diberikan multivitamin. Populasi penelitian ini adalah semua anak balita di Wilayah Kerja Puskesmas Pagelaran Kabupaten Pringsewu berjumlah 2920 balita. Sampel diambil dengan metode consecutive sampling dan diperoleh jumlah sampel sebanyak 100 responden dengan perbandingan 1:1 dimana kelompok pijat Tuina sejumlah 50 orang, dan kelompok yang diberikan multivitamin sejumlah 50 orang. Adapun kriteria sampel adalah tidak menerima pengobatan tertentu, tidak mengalami kelainan neurologis yang mempengaruhi kemampuan makan, tidak terdiagnosis menderita penyakit kronik, tidak mengalami kelainan struktural/anatomi tubuh di bagian naso-orofaring, laring dan trakea dan esophagus. Selanjutnya data penelitian kesulitan makan dikumpulkan dengan menggunakan kuesioner sebelum dan sesudah diberikan perlakuan langsung menggunakan job sheet, baik pada kelompok perlakuan maupun kelompok kontrol. Pada kelompok perlakuan pemijatan Tui Na dilakukan selama 6 hari dengan 8 langkah set terapi, selanjutnya dilakukan penilaian dengan kuesioner pada hari ke-7. Data yang terkumpul selanjutnya diproses dan dianalisis dengan Uji T. 


\section{HASIL}

Tabel 1: Distribusi Rata-rata Kesulitan Makan Sebelum dan Sesudah pada Kelompok Eksperimen dan Kontrol.

\begin{tabular}{|c|c|c|c|c|c|}
\hline Kesulitan Makan & Mean & $S D$ & $\begin{array}{c}\text { SE } \\
\text { Mean }\end{array}$ & $\begin{array}{c}p- \\
\text { value }\end{array}$ & $\mathrm{n}$ \\
\hline $\begin{array}{l}\text { Sebelum - Setelah } \\
\text { Pijat Tuina }\end{array}$ & 3.360 & 0.921 & 0.130 & & 50 \\
\hline $\begin{array}{l}\text { Sebelum - Setelah } \\
\text { diberi multivitamin }\end{array}$ & 2.260 & 1.337 & 0.189 & & 50 \\
\hline
\end{tabular}

Rata-rata selisih kesulitan makan sebelum dan sesudah pada anak yang dilakukan pijat tuina adalah 3.360 dengan standar deviasi 0,921 sedangkan untuk anak balita yang diberi multivitamin ratarata adalah 2.260 dengan standar deviasi 1.337. Hal ini berarti menunjukan bahwa selisih rata-rata kesulitan makan pada anak yang dilakukan pijat tuina lebih besar dari anak yang diberikan multivitamin.

Berdasarkan hasil uji uji statistik didapatkan nilai $\mathrm{p}=0,000$, dengan alpha $5 \%$ berarti ada perbedaan rata-rata kesulitan makan pada anak balita yang dilakukan pijat tuina dengan anak balita yang diberikan multivitamin. Perbedaan ini menunjukan bahwa melakukan pijat tuina lebih efektif dalam mengatasi kesulitan makan pada anak balita dibandingkan dengan pemberian multivitamin.

\section{PEMBAHASAN}

Hasil penelitian menggambarkan bahwa tindakan pijat tuina lebih efektif dalam mengatasi kesulitan makan pada anak balita daripada pemberian multivitamin. Berdasarkan uji t test dapat diketahui bahwa rata-rata perubahan kesulitan makan sebelum diberikan treatment pada kelompok eksperimen adalah 3,360 dengan standar deviasi 0,921, sedangkan untuk anak balita yang diberi multivitamin adalah 2.260 dengan standar deviasi 1.337. Hasil uji statistik didapatkan nilai $\mathrm{p}=0,000$, berarti ada perbedaan rata-rata perubahan kesulitan makan pada anak balita antara anak balita yang dilakukan pijat tuina dengan anak balita yang diberikan multivitamin.

Kejadian kesulitan makan sebelum treatment dialami oleh seluruh responden yang berkunjung (100\%). Kejadian kesulitan makan ini disebabkan karena penerimaan makanan yang tidak/kurang memuaskan, makan tidak mau ditelan, Makan terlalu sedikit atau tidak nafsu makan, penolakan atau melawan pada waktu makan., Kebiasaan makan makanan yang aneh (pika), Hanya mau makan jenis tertentu saja, cepat bosan terhadap makanan yang disajikan, dan Kelambatan dalam tingkat keterampilan makan dan keluhan lain.

Kesulitan makan pada anak balita terbanyak disebabkan cepat bosan terhadap makanan yang disajikan. Hal ini menuntut agar orang tua dapat belajar untuk bisa menyajikan makanan dengan bentuk dan rasa yang disukai oleh anakanak, selain itu banyak anak yang mengalami kelambatan dalam tingkat ketrampilan makan, dimana pada usia balita (pra sekolah) anak- anak masih banyak yang butuh disuapi oleh orang tuanya.

Menurut Judarwanto (2004), kesulitan makan ditandai dengan perilaku memuntahkan makanan yang ada didalam mulut anak, makan dalam waktu yang lama, tidak mau memasukkan makanan ke mulut, membuang makanan dan menepis suapan dan beberapa orang tua menyatakan anak tidak mau saat diberikan makanan. Anak pra sekolah dapat menyadari bahwa dirinya tidak sepenuhnya bergantung pada lingkungan sekitarnya, anak menuntut adanya otonomi bagi dirinya seperti dengan menolak saat diberikan makanan.

Anak balita memiliki rasa ingin tau yang tinggi dan mereka tertarik untuk memenuhi banyak hal dengan rasa ingin tahunya, sehingga sibuk mengeksplorasi lingkungan di sekitarnya. Menurut Wardlaw dan Hampl (2007), karena kesibukan mengeksplorasi lingkungannya terkadang mengalihkan anak dari makanannya. Selain itu anak juga memiliki rasa curiga jika disediakan 
makanan yang baru dikenalnya karena memiliki indra pengecap yang lebih sensitif dibandingkan orang dewasa, akibatnya hanya menyukai jenis makanan tertentu yang berganti-ganti selama kurun waktu tertentu (Sutardjo, 2011).

Pijat Tui $\mathrm{Na}$ ini dilakukan dengan tehnik pemijatan meluncur (Effleurage atau Tui), memijat (Petrissage atau Nie), mengetuk (tapotement atau Da), gesekan, menarik, memutar, menggoyang, dan menggetarkan titik tertentu sehingga akan mempengaruhi aliran energi tubuh dengan memegang dan menekan tubuh pada bagian tubuh tertentu. Pijat Tui $\mathrm{Na}$ ini merupakan tehnik pijat yang lebih spesifik untuk mengatasi kesulitan makan pada anak balita dengan cara memperlancar peredaran darah pada limpa dan pencernaan, melalui modifikasi dari akupunktur tanpa jarum, teknik ini menggunakan tenik penekanan pada titik meridian tubuh atau garis aliran energi sehingga relatif lebih mudah dilakukan dibandingkan akupuntur (Sukanta, 2010).

Penyebab tersering pada kasus kesulitan makan pada anak balita dikarenakan gangguan fungsi limpa dan pencernaan. Sehingga makanan yang masuk kedalam perut tidak segera dicerna, yang berakibat pada stagnasi makanan dalam saluran cerna, keluhan yang disampaikna orang tua pada masalah ini adalah anak sering muntah, mual jika disuapi, dan perut terasa penuh sehingga mengurangi nafsu makan atau bahkan tidak nafsu makan sama sekali. Pijat ini akan memperlancar peredaran darah ke limpa dan pencernaan, hal ini didukung oleh penelitian yang dilakukan oleh Zhen Huan Liu dan Li ting Cen di Guangzhou tahun 2009 menyebutkan bahwa pijat Tui na berpengaruh positif terhadap perkembangan syaraf dan peredaran darah pada bayi. Penelitian serupa juga dilakukan oleh Joko Widodo dkk (2012) didapatkan bahwa akupresur pada titik meridian tertentu dapat memperlancar aliran darah ke pencernaan

Berdasarkan hasil penelitian yang telah dilakukan di 3 BPM Wilayah Pagelaran dengan sampel 100 responden, dengan 50 responden untuk eksperimen dilakukan treatment dengan Pijat Tuina dan 50 responden sebagai kontrol dengan diberikan multivitamin didapatkan mayoritas responden berusia 12-35 bulan (Anak Batita) yaitu 68 orang (68\%).

Hal ini sejalan dengan penelitian Beautris (2007) yang menyatakan bahwa terdapat $24 \%$ responden di New Zaeland yang mengatakan anaknya mengalami kesulitan makan diusia 2 tahun dan $18 \%$ diantaranya berlanjut sampai usia 4 tahun. Hal ini juga sesuai dengan teori bahwa kesulitan makan sering dialami oleh anak terutama rentang usi 1-3 tahun yang disebut juga usia food jag, yaitu anak hanya makan pada makanan yang disukai atau bahkan sulit makan (Afiani L. Ika dkk, 2003). Dikategorikan kesulitan makan jika ibu menjawab isian kuisioner lebih dari 2 tanda / indikator kesulitan makan. Beberapa indikator tanda kesulitan makan pada balita yakni: kesulitan mengunyah, menghisap, menelan, memuntahkan atau menyemburkan makana yang sudah masuk di mulut, memainkan makanan atau makan berlamalama, sama sekali tidak mau memasukkan makanan kedalam mulut atau menutup rapat mulut, memnuntahkan atau menumpahkan makanan, menepis suapan, tidak menyukai banyak variasi makanan, dan kebiasaan makan yang tidak biasa. (Widodo, 2012)

Berdasarkan hasil penelitian, didapatkan mayoritas responden berjenis kelamin perempuan yaitu 73 orang $(73 \%)$ responden. Hasil ini sejalan dengan hasil penelitian yang dilakukan Otsberg dan Hagelin (2010), yang mengatakan bahwa anak perempuan lebih banyak mengalami kesulitan makan dibanding anak laki-laki.

Namun, hasil ini tidak sejalan dengan hasil penelitian Sudibyo dan Mulyani (2009) yang menyatakan kesulitan makan lebih banyak dialami anak laki-laki dari pada perempuan, karena anak laki-laki lebih aktif dari pada perempuan, sehingga lebih banyak lakilaki yang mengalami kesulitan makan dari pada perempuan. 
Kejadian kesulitan makan di Pagelaran terbanyak pada anak perempuan, kemungkinan disebabkan karena pengambilan sampel dilakukan dengan teknik consecutive sample, dimana yang diambil sebagi responden adalah anak balita yang berkunjung ke BPM dan mengalami masalah kesulitan makan, kemungkinan faktor penyebab kesulitan makan pada anak balita di Pagelaran yaitu faktor internal dan eksternal. Faktor internal meliputi gangguan pencernaan dan gangguan psikologis. Faktor eksternal meliputi faktor kesukaan makan, faktor kebiasaan makan, dan faktor lingkungan.

\section{KESIMPULAN}

Berdasarkan hasil penelitian dapat ditarik kesimpulan pemberian pijat tuina pada anak balita lebih efektif untuk mengatasi kesulitan makan dari pada pemberian multivitamin $(\mathrm{p}=0,000)$. Dimana pada balita yang diberikan pijat tuina mengalami perubahan rata-rata kesulitan makan sebesar 3,360 dengan standar deviasi 0,921, sedangkan pada balita sebesar 2.260 dengan standar deviasi 1.337 .

Berdasarkan kesimpulan penulis menyarankan kepada pada orang tua, agar dapat melaksanakan prosedur pijat tuina dalam mengatasi kesulitan makan pada anaknya. Selanjutnya bagi dinas kesehatan dan puskesmas agar dapat memberikan edukasi dan pelatihan tentang pijat tuina kepada seluruh orang tua yang berkunjung, agar memanfaatkan teknik pijat tuina sebagai cara dalam mengatasi kesulitan makan pada anak balita

\section{DAFTAR PUSTAKA}

Chung KM, Kahng SW. Pediatric feeding disorders. Dalam: Fisher JE, O'Donohue WT, penyunting. Practitioner's guide to evidencebased psychotherapy. New York: Springer; 2006. p. 514.

Afiani, L.I., dkk. 2003. Ramuan jamu cekok sebagai penyembuhan kurang nafsu makan pada anak. Jurnal Makara kesehatan, Vol. 7, No 1, Juni 2003. UGM: Yogyakarta

Sukanta, P. Okta. 2010. Akupressur \& Minuman untuk Mengatasi Gangguan Kesehatan Reproduksi. Jakarta: PT Elex Media Komputindo.

Sutarjo, Djoko, 2014. Kesulitan Makan pada Anak. rsudpatikab, co.id. Diakses 29 Mei 2017.

WHO. International classification of disease: feeding difficulties [Internet]; 2012. [Cited 2012, February 20]; Available from: http://www.icd10data.com/ICD10C M/Codes/R00-R99/R50-R69/R63/R63.3

Widodo, Joko. 2012. Edukasi dan konsultasi sulit makan dan gangguan kenaikan berat badan. Jakarta: Picky Eaters And Grow Up Clinik. http:// pickyeatersclinik.com akses 27 Mei 2017 jam 11.00

Zhen Huan Liu., Li-ting Cen. 2011. Effect Tui $\mathrm{Na}$ On Neurodevelopment in Premature Infant. Journal of Acupuncture and Tuina Science. Vol. 11, Issue 1, pp7-12. 